\title{
Product innovation agility on business performance: The role of market and learning orientation
}

\section{Agilidad de innovación de productos en el rendimiento empresarial: el papel del mercado y la orientación al aprendizaje}

\author{
Mulyana Mulyana*, Sutapa Sutapa, Wasitowati Wasitowati \\ Universitas Islam Sultan Agung, Indonesia
}

Received December 17, 2018; accepted September 11, 2019

Available online September 10, 2019

\begin{abstract}
This paper aims to investigate the effect of market orientation (MO), product innovation agility (PIA) and Learning orientation (LO) on business performance (BP). Data were collected from 205 creative industries in Indonesia and were analyzed by using Structural Equation Modeling (SEM). The result shows that market orientation, product innovation agility and learning orientation affect business performance. Furthermore, product innovation agility mediates the correlation of market orientation and learning orientation on business performance. This paper contributes to solve the results of previous studies on the relationship between market orientation, learning orientation and business performance.
\end{abstract}

JEL code: M31, L25

Keywords: Market orientation; Learning orientation; Product innovation agility; Business performance

\footnotetext{
* Corresponding author.

E-mail address:mulyana@unissula.ac.id (Mulyana).

Peer Review under the responsibility of Universidad Nacional Autónoma de México. 


\section{Resumen}

Este documento tiene como objetivo investigar el efecto de la orientación al mercado (MO), la agilidad de innovación de productos (PIA) y la orientación al aprendizaje (LO) sobre el rendimiento empresarial (BP). Se recopilaron datos de 205 industrias creativas en Indonesia y se analizaron mediante el modelo de ecuaciones estructurales (SEM). El resultado muestra que la orientación al mercado, la agilidad en la innovación de productos y la orientación al aprendizaje afectan el desempeño empresarial. Además, la agilidad de la innovación de productos media la correlación de la orientación al mercado y la orientación al aprendizaje en el desempeño empresarial. Este artículo contribuye a resolver los resultados de estudios previos sobre la relación entre orientación al mercado, orientación al aprendizaje y desempeño empresarial.

Código JEL: M31, L25

Palabras clave: Orientación del mercado; Orientación al aprendizaje; Agilidad de innovación de productos; El rendimiento del negocio

\section{Introduction}

The creative industries significantly contribute to economic development, especially in providing jobs and increasing people's salary. The creative industries development needs support and guidance to compete in the global market. With various limitations, they should innovate and have learning oriented in this dynamic environment. Creativity and innovation are indispensable for creative industries to grow and develop. Good creative industry players include of individuals who have ability to take on challenges, have a strong desire to achieve business goals (Abi and Abdul, 2011).

The role of market orientation and learning orientation require innovation agility to improve business performance. Creativity and agility of product innovation in finding the new, unique and different ideas are needed to compete in market. Market orientation is a company resource that can lead organizations to create sustainable competitive advantage. It involves customers, competitors and internal coordination among its functions. Marketing activities on market orientation should understand the organizational culture of the company in order to get support from the organization members in preparing the company's strategy. Mar- 
ket-oriented business activities can enhance innovation and business performance (Suliyanto, 2012). Learning orientation is one of the strategies for strengthening innovation and as an open mindset that encourages business performance improvement (Martinette et al, 2012).

The dynamics of competition increase tightly so that creativity and innovation are needed to adjust to environmental changes. Market learning orientation in creative industry becomes a necessity and should be done with a strong commitment to achieve the vision and goals. Learning orientation and continuous product innovation for the creative industry are needed to compete and improve performance in adapting to the global markets.

Some previous studies showed inconsistent results. Market orientation can improve business performance (Kohli, 1993; Takata, 2016; Zainul \& Utami, 2016; Kaswuri, 2016; Masa'deh et al., 2018; Herman \& Arafah, 2018; Bhattarai \& Tasavori, 2019). Other studies showed that market orientation is not able to improve business performance (Keskin, 2006; Mahmoud et al., 2016; Solano \& Collado, 2018; Idrus \& Abdussakir, 2018). Likewise, proactive market orientation cannot improve business performance while responsive market orientation can improve business performance (Kocak \& Oflazoglu, 2017). The dimensions of market orientation, namely customer orientation and competitor orientation have no effect on business performance while inter-functional coordination has an effect on business performance (Migdadi et al., 2017). Customer orientation and competitor orientation can improve business performance, while interfunctional coordination is not able to improve business performance (Ansah \& Chinomona, 2017).

Study show that learning orientation can improve business performance (Aloulou, 2018). Learning orientation can encourage organizational performance, such as the speed of shipping of goods, cost efficiency, quality of trust and future performance of the company (Tajeddini, 2016). Other studies show different results, learning orientation is not able to improve business performance (Dutta et al., 2017; Ebrahimi et al., 2018). Several studies on innovation have been carried out by previous researchers, for example, product innovation and environmentally friendly processes (Chang, 2011), process innovation and product innovation (Shu and Xiao, 2016), incremental and radical innovation (Kocak et al., 2017), exploratory and exploitative innovation (Wagner et al., 2018). In this study, it focuses on product innovation agility.

The purpose of this study is to examine the influence of market orientation, product innovation agility, learning orientation on performance. It is important to conduct this research because the gap from the results of previous studies could be solved. Furthermore, the result of this study is expected to contribute the development of creative industries in facing the tight competition in the global market. 


\title{
Literature Review
}

\author{
Business Performance
}

Venkatraman (1986) stated that the Concept of measuring business performance using a variety of schemes has advantages and limitations so that business performance measurement can adopt the most appropriate approach. Sin \& Lee (2002) used indicators of customer retention, sales growth, market, return on investment and overall performance to measure business performance. Furthermore, Nwokah \& Maclayton (2006) stated that business performance can be measured through indicators of corporate profits, market share and sales growth achieved by the company. Sin \& Tse (2006) describe the way to measure business performance through aspects such as sales growth, customer retention, return on investment (ROI), market share, trust, customer satisfaction, and sales return.

Business performance is a combination of financial and marketing performance (Sulistyo \& Siyatinah, 2016; Jaakkol et al., 2010; Jogaratnam, 2017). Market performance describes efforts to increase market share and sales volume, while financial performance describes financial measures, such as profit margins, return on investment that has been achieved. Sharabati et al (2010), business performance can be measured through profitability, productivity and market valuation. Najib \& Kiminami (2011), explained that sales volume, profitability and market share are indicators for measuring business performance. Furthermore, Nuryakin et al. (2018) stated that business performance is a result of the organization's operational activities which include the achievement of internal and external results. Business performance was measured through the performance of sales volume, sales growth, profitability and market share. This business performance study is measured through return on assets, growth profit, sales growth, and market share growth.

\section{Market Orientation}

Slater \& Narver (1990) explained that market orientation was identified into three components: customer orientation, competitor orientation and inter-functional coordination. Customer orientation is expected to understand the target buyer timely to create superior value. Competitor orientation aims to get information on the main competitors and potential competitors and understand the strengths and weaknesses of competitors in the short and long term. Inter-functional coordination is used in order the human resources can be well coordinated to create superior value for the target market. 
Kohli and Jaworski (1993) defines market orientation as the construction of three components of activity, including generational intelligence, market intelligence dissemination and organizations responsive to disseminated intelligence. Furthermore, market orientation will gain market knowledge and respond as quickly as possible so that it can create a good performance for the company. Wan \& Muhammad (2013) explained that market orientation is a dynamic component and can improve company performance. Kocak et al., (2017) states that market orientation can be responsive and proactive as an antecedent of business performance.

\section{Learning Orientation}

Huber (1991) explained that learning orientation is the development of new knowledge that will have an impact on values and beliefs. Sinkula \& Baker (1997), learning orientation is a concept that involves organizational values so that they tend to create new knowledge. Learning orientation can be measured through three dimensions: commitment to learning, open-mindedness and shared vision (Sinkula \& Baker, 1997), define learning orientation as an organizational activity to develop and increase knowledge in order to create competitive advantage and can improve company's innovativeness. Martinette (2006) explained that learning orientation is done with a strong commitment that will make it easier to achieve the vision and goals as well as improve business performance. Tajeddini (2016) states that learning orientation is the ability and willingness to continue learning which can increase trust, cooperation, and cost efficiency for the company.

\section{Product innovation agility}

Raschke \& David, (2005) said that agility is a dynamic ability to modify and reconfigure business processes that are selected from a series of business process capabilities to accommodate the needs and potential of the company. David et al. (2016) explained that agility is the capacity of an organization to efficiently and effectively direct human resources to create and protect the value obtained in the face of environmental changes. Holbeche (2018) defines agility as the ability of organizations to respond and adapt quickly to environmental changes. Furthermore, the main principles of agility are the focus of a strong future, anticipation, and response to trends and threats, collaboration with customers, innovation, and empowerment. Agility needs change that must be supported by all parties so that the continuity of learning is needed (Holbeche, 2018). According to Kuncoro \& Suriani (2018), product innovation is the overall operation of the company to create new products including all processes carried 
out. In this study, product innovation agility is the organization's ability to product innovation effectively and efficiently to respond the environmental changes.

\section{Hypotheses development and empirical research model}

Market Orientation and Product Innovation Agility

Agility becomes as a key to develop new products in order to be able to meet market needs (Schuh et al., 2017) and agility has a strong relationship with radical product innovation (Oliveira, 2017). Likewise, proactive market orientation can encourage the creation of radical innovation (Kocak et al., 2017) and improve innovation capabilities (Lakshman \& Adhikari, 2017). Studies show that market orientation can improve innovation (Suliyanto, 2012; Remli \& Muhammad, 2013). In small and medium enterprises, the high market orientation will improve the product innovation, process innovation, market innovation and management innovation. Companies that try to understand the market will be encouraged to meet product needs according to customer desires so that they are motivated to increase product innovation capabilities. Customer orientation policy by understanding customer expectations and feedback can drive the organization's speed and agility to innovate new products (Elkareem et al, 2011). Therefore, in an effort to meet product needs based on customer expectations better, understanding competitors and inter-functional coordination are likely to encourage product innovation agility.

H1: Market orientation significantly affects product innovation agility.

\section{Learning orientation and product innovation agility}

Learning orientation is related to innovation that can be implemented in the form of ideas, processes, products, and services (Day, 1994). Learning orientation can improve company's innovativeness (Mahmoud, 2016). Companies that have a commitment to market learning orientation will be motivated to realize product innovation capability. All learning orientation activities will contribute to improve product innovation capabilities. Learning orientation can enhance experience and knowledge so that it can increase the agility of new product innovations (Elkareem et al, 2011). Learning orientation encourages the success of corporate innovation (Mahto et al., 2018) and has an effect on improving product quality, production flexibility and speed of new product promotion (Huang \& Li, 2017). The ability to learn from 
experience and failure can affect innovation agility (Carmeli \& Dothan, 2017). Therefore, the willingness to learn and gain new knowledge in realizing product innovation based on market needs will encourage product innovation agility.

H2: Learning orientation significantly affects product innovation agility.

\section{Market orientation and business performance}

The relationship between market orientation and business performance has been done in some studies. Studies show that market orientation can positively improve company performance (Kohli \& Kumar, 1993; Takata, 2016; Zainul et al., 2016; Kaswuri et al., 2016; Nikraftar \& Momeni, 2017; Ho, Nguyen et al., 2018; Bhattarai et al., 2019; Musa et al., 2019; Fernandes et al., 2019). Market orientation is also a determinant of the business performance of women entrepreneurs (Aliyu \& Nordin, 2019). Market orientation contributes to improve business performance when facing turbulent environmental changes (Bereket, 2017) and it is the antecedents of marketing performance and financial performance (Tajeddini \& Ratten, 2017). Likewise, responsive market orientation can improve company performance (Kocak et al., 2017). Therefore, companies that are able to develop marketing programs well through customer orientation, competitor orientation and inter-functional coordination, can improve business performance.

H3: Market orientation significantly affects business performance

\section{Learning orientation and business performance}

Studies show that learning orientation can improve business performance (Aloulou, 2018; Nikraftar \& Momeni, 2017). Effective learning orientation can improve financial performance (Chen \& Wey, 2017) and encourage better organizational performance in terms of speed of product delivery, cost efficiency, quality of trust and future performance (Tajeddini, 2016). Learning orientation can improve company performance (Dutta et al., 2016; Tajeddini, 2016) and can improve the new products performance (Li, 2017). Learning orientation and innovation must be encouraged in order to improve the better performance. A high level of learning orientation and innovation will encourage organization's quality, cost efficiency and confidence in high performance (Tajeddini, 2016). Therefore, market learning orientation in a company can improve business performance. Likewise, company activities market-oriented 
will encourage learning organizations that are always based on market-oriented so that they have an impact on business performance.

H4: Learning orientation significantly affects business performance.

\section{Product innovation agility and business performance}

Product innovation is one determinant of business performance (Mahmud \& Hasyim, 2018; Herman et al., 2018). The speed of product innovation will affect the success of the product in the market and have an impact on improving the company performance, such as the growth of market share, sales, and profits (Mitrega et al., 2017). Product innovation by continually improving product quality, introducing new products, developing new markets, and using new technologies can encourage increased company performance (Mitrega et al., 2017). Studies show that radical innovation also affect business performance (Kocak et al., 2017). Agility has a strong relationship with radical product innovation, which has an impact on improving business performance (Oliveira, 2017). Agility allows the work team to quickly create and communicate decisions on developing new products (Rebentisch et al., 2018). Likewise, organizational agility has a strong influence on company performance (Ravichandran, 2018). The better innovation capability (new product, process, management and marketing) undertaken by small and medium enterprises will make the better company performance (Sulistyo \& Siyamtinah, 2016). Agility will be able to improve market performance when decision makers have market skills, experience, and learning orientation (Nemkova, 2017). Therefore, product innovation agility based on market needs allows an increase in business performance.

H5: Product innovation agility significantly affects business performance

\section{The mediation role of product innovation agility}

Agility is an approach to manage and provide a fast and reconfiguring system to deal with rapid environmental changes (Bernardes \& Hanna, 2009). Organizational culture in customer orientation by understanding customer expectations and feedback can drive the organization's speed and agility to innovate new products. Furthermore, learning orientation enhances experience and knowledge and increases the agility of new product innovations (Elkareem 
et al., 2011) and organizational agility will determine the quality of the decisions that are determined (Kock \& Gem, 2016). Agility allows the work team to take decisions quickly on developing new products and the efficiency of the completion of new products (Rebentisch et al., 2018). The higher the agility, the faster the radical product innovation and it will impact on improving business performance (Oliveira, 2017).

Agility needs the support of all parties to create better changes so that continuous learning orientation is needed (Holbeche, 2018). Agility will be able to improve market performance when decision makers have marketable skills, experience, learning orientation (Nemkova, 2017). Furthermore, when the organization has agility, it will encourage the increased of market performance. According to Tajeddini (2016), organizations that are open to find new ideas, products and process innovation with new technologies, can improve business performance. Dynamic environmental changes determine the adaptive agility so that it affects the company's performance. Therefore, the company's speed in meeting product needs that is suitable for customer expectation requires product innovation agility, so that it will impact on business performance. Besides that, learning orientation that is directed to gain new product knowledge that is suitable with customer expectations will encourage product innovation agility, thus it also impacts business performance.

H6: Product innovation agility mediates the relationship between market orientation and business performance.

H7: Product innovation agility mediates the relationship between learning orientation and business performance.

\section{Methodology}

\section{Research Framework}

The object of this research is the fashion creative industries in Central Java, Indonesia. This research was conducted on since February to April 2018. The analysis unit of this research is the managers or owners of the creative industry. The researchers consider that the managers or owners have experiences in managing business and have outlook and ethics in the importance of market orientation, learning orientation, and also product innovation agility which becomes an effort to improve higher business performance. 


\section{Variable definition and measurement}

To test the proposed hypothesis, a questionnaire that has good validity content is needed. The questionnaire built will be used to test market orientation, learning orientation, product innovation agility, and business performance. Primary data and secondary data were used in this study. Primary data is obtained through questionnaires and face-to-face interviews. Primary data which is obtained through questionnaires will be tested for validity and reliability to ensure good validity and consistency of all instruments. The distribution of questionnaires was carried out to get responses from creative industry owners or managers from 5 districts/ cities in Central Java.

Furthermore, face-to-face interviews with managers or owners are also carried out to check the accuracy of information, validate results and develop an understanding of the questionnaire. In-depth interviews and questionnaires collected will be used to measure market orientation, learning orientation, product innovation agility, and business performance. All constructs of 5-point Likert scale is ranked from "strongly disagree" (1) to "strongly agree" (5). Operational definition of each variables are as follows:

Market Orientation. Market orientation is an organizational culture that has confidence and values that put customers in the center of business decisions, and measured through 9 indicators adopted from (Asikhia, 2014), they are: value added for consumers, understanding consumer needs, customer satisfaction, information sharing competitors, competitor action responses, competitor strategy responses, inter functional coordination, information sharing among parts, and cooperation formulate strategies.

Product Innovation Agility. Product innovation agility is the ability of an organization to innovate products effectively and efficiently to respond the environmental changes, which is measured by 4 indicators adopted from (Elkareem et al., 2011), they are: products based on customer needs, develop and market products flexibly, develop products based on customer tastes, ability to change products on demand.

Learning Orientation. Learning orientation is the company ability to improve employees' capability and build their confidence to adapt with the market environment changes which is measured by 4 indicators developed by (Suliyanto and Rahab, 2012), they are: improve the ability of marketing employees, improve the skills of marketing employees, develop trust among marketing employees, think the market environment changes.

Business Performance. Business performance is the ability to dominate the market and focus on its goal marketing and financial. It is measured by 4 indicators adopted from (Wingwon, 2012; Karacaoglu et al. 2013), they are: return on assets, profit growth, sales growth, market share growth. 


\section{Research sample}

Data collection through face-to-face interviews and questionnaires was conducted. This study uses market orientation variables, learning orientation, product innovation agility, and business performance. Respondents selected were 376 managers or creative industry owners in Central Java, Indonesia. Questionnaires collected and filled as much as 265 of the total respondents. The total of unfilled questionnaires was 44 respondents, so the data processed was 221 respondents. During the data processing, there are still 16 data that are extreme and inappropriate to use. The total sample of this study was 205 respondents or $54.5 \%$ of the total respondents. Data is collected from 5 districts/cities representing creative industry owners or managers in Central Java, Indonesia.

\section{Data analysis and measurement model}

The SEM approach has been used to process the data in order to test the hypotheses. SEM is used to examine the relationship between market orientation, learning orientation, product innovation agility, and business performance. Data analysis using SEM consists of two types of variables, namely latent variables and observed/manifest. The latent variable cannot be observed directly but it is observed through an indicator that is reflected in the construct that is developed when the observed variable can be observed directly. Model match evaluation with Confirmatory Factor Analysis is in table 1.

In table 1, all constructs have good reliability, this shows there is internal consistency. It means that the construct latent can be measured consistently through all indicators (Hair et al, 2010). Reliability (CR) is more than 0.6, Variance Extracted (VE) is more than 0.5, and this is in accordance with the internal consistency standard of the measured indicator. Table 2 shows $\mathrm{CR}$ value is more than 0.7 , VE is more than 0.7 , for market orientation, learning orientation, product innovation agility, and business performance. 
Table 1

Confirmatory Factor Analysis Result for the Measurement Model

\begin{tabular}{|c|c|c|}
\hline Indicator & $\begin{array}{l}\text { Loading } \\
\text { factor }\end{array}$ & p-value \\
\hline \multicolumn{3}{|l|}{ Market Orientation: } \\
\hline The company creates value-added of products for consumers as always & 691 & 0.000 \\
\hline The company is trying to understand consumer needs & .785 & 0.000 \\
\hline The company makes every effort to provide customer satisfaction & .745 & 0.000 \\
\hline The seller explores about the competitor information & .753 & 0.000 \\
\hline The company responds quickly to the actions of competitors & .817 & 0.000 \\
\hline The company always responds to the competitors' strategies & .771 & 0.000 \\
\hline There is coordination among subordinates in the company & .832 & 0.000 \\
\hline Information sharing among subordinates is required by the company & .813 & 0.000 \\
\hline There is cooperation among subordinates to formulate marketing strategy & .790 & 0.000 \\
\hline \multicolumn{3}{|l|}{ Product Innovation agility: } \\
\hline The company adapts its products based on the customer needs. & .881 & 0.000 \\
\hline $\begin{array}{l}\text { The company has flexible capabilities that can develop and deliver different } \\
\text { products }\end{array}$ & .897 & 0.000 \\
\hline The company develops its products based on the customers tastes & .884 & 0.000 \\
\hline $\begin{array}{l}\text { The organization has the ability to change the size of its products in accordance } \\
\text { with the increase or decrease in demand } \\
\text { Learning Orientation: }\end{array}$ & .736 & 0.000 \\
\hline The company has efforts to improve the employee's ability & .822 & 0.000 \\
\hline The company has efforts to improve the employee's skills & .853 & 0.000 \\
\hline The company has efforts to develop trust among the employees & .888 & 0.000 \\
\hline The company encourages the employees to think about the changes & .765 & 0.000 \\
\hline \multicolumn{3}{|l|}{ Business Performance: } \\
\hline Return on Asset (ROA) in my business has increased over the years & .806 & 0.000 \\
\hline My business profit grows over the years & .776 & 0.000 \\
\hline Sales increased over the years & .743 & 0.000 \\
\hline My market share increased over the years & .743 & 0.000 \\
\hline
\end{tabular}

Source: data was calculated by SEM

Table 2

Construct Reliability, Correlation and AVE

\begin{tabular}{lllll}
\hline $\mathrm{N}=205$ & 1 & 2 & 3 & 4 \\
\hline $\begin{array}{l}\text { Market Orientation } \\
\text { Learning Orientation }\end{array}$ & 0.932 & & & \\
& & & & \\
0.625 & & & & \\
& & & & \\
0.893 & & & & \\
Product Innovation Agility & 0.567 & 0.504 & 0.913 & \\
Business Performance & 0.685 & 0.643 & 0.675 & 0.851 \\
\hline AVERAGE Variance Extracted (AVE) & 0.607 & 0.719 & 0.726 & 0.589 \\
\hline
\end{tabular}

Source: data was calculated by SEM 


\section{Results}

The results of the initial structural model test before there is a mediating variable, it indicates a good Goodness-of-Fit index. The value of X2 = 207,944 is not significant at $\alpha 0.05$, the GFI index is 0.91; AGFI 0.89; TLI 0.99; CFI 0.99; RMSEA $0.02<0.08$ and CMIN / DF 1.13 $<2.00$, all values are in accordance with the criteria recommended by SEM.

Table 3 and Figure 1 show the direct effect of $\mathrm{MO}$ on $\mathrm{BP}(\operatorname{Std} \beta=0.314, \mathrm{CR}=3.816, \mathrm{p}$ $<0.01)$; $\mathrm{LO}$ to BP $(\mathrm{Std} \mathrm{b}=0.262, \mathrm{CR}=3.312, \mathrm{P}<0.01)$ and PIA to BP $(\mathrm{Std} \mathrm{b}=0.374, \mathrm{CR}=$ 4.982, $\mathrm{P}<0.01)$. It can be concluded that MO, LO and PIA partially have a significant effect on BP.

Table 3

Direct effect of MO, LO, PIA on BP

\begin{tabular}{ccccc}
\hline & Effect & Std $\beta$ & SE $\beta$ & C.R. \\
\hline MO -> BP & .314 & .086 & $3.816^{*}$ \\
LO -> BP & .262 & .092 & $3.312^{*}$ \\
PIA ->BP & .374 & .073 & $4.982^{*}$ \\
\hline
\end{tabular}

Note: $*<0.01$

Source: data was calculated by SEM

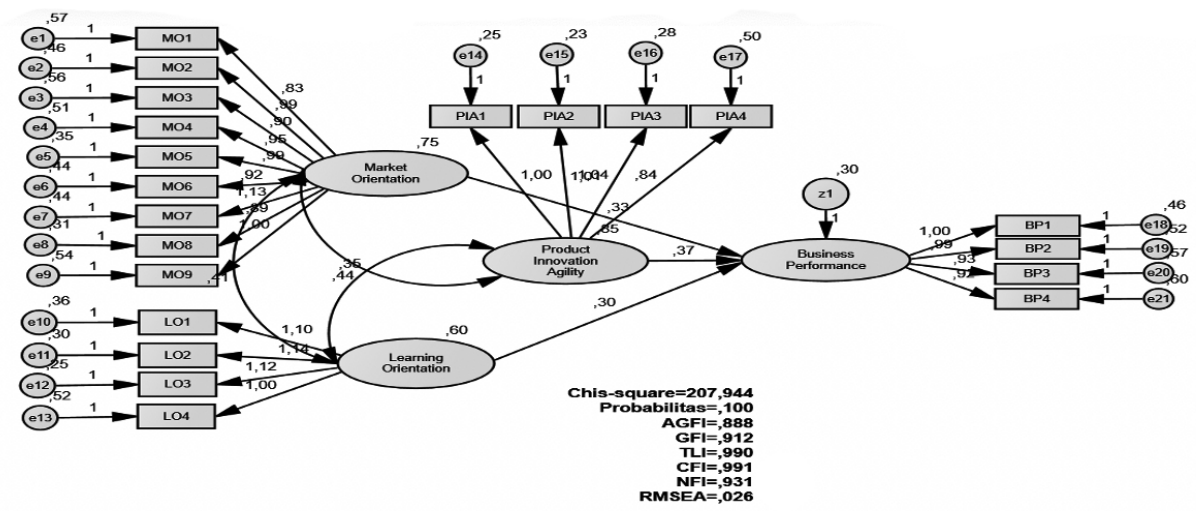

Figure 1. Initial structural model Source: data was calculated by SEM 
The results of the final structural model after there is mediating variables show a good Goodness-of-Fit index and are in accordance with the criteria recommended by SEM. The value of $\mathrm{X} 2=211.278$ shows no significant at $\alpha 0.05$, GFI index 0.94; AGFI 0.89; TLI 0.98 ; CFI 0.98, so all values $\geq 0.90$ except AGFI 0.89. Furthermore, RMSEA .029 is smaller than 0.08 and CMIN / DF 1,174 is smaller than 2,00, so that all values are in accordance with the recommended SEM. Therefore, the fits or proper model is used to test the relationship among variables in this study.

Table 4

Parameter estimation of the path: direct and indirect effects

\begin{tabular}{lccl}
\hline Effect & Std $\beta$ & SE $\beta$ & C.R. \\
\hline H1 : MO ->PIA & .540 & .118 & $4.558^{*}$ \\
H2 : LO-> PIA & .265 & .094 & $2.831^{*}$ \\
H3 : MO -> BP & .398 & .107 & $3.709 *$ \\
H4 : LO -> BP & .277 & .083 & $3.350^{*}$ \\
H5 : PIA -> BP & .355 & .072 & $4.925^{*}$ \\
H6 : MO -> PIA -> BP & .191 & .000 & $3.354^{*}$ \\
H7 : LO -> PIA -> BP & .094 & .007 & $2.447^{*}$ \\
\hline
\end{tabular}

Note: $* \mathrm{p}<0.01$

Source: data was calculated by SEM

Table 4 and Figure 2 show a significant positive direct effect between MO and PIA (Std $\beta$ $=.540, \mathrm{CR}=4.558, \mathrm{p}<0.01)$, between LO and PIA ( $\operatorname{Std} \beta=.265, \mathrm{CR}=2.831, \mathrm{p}<0.01)$, between $\mathrm{LO}$ and $\mathrm{BP}(\operatorname{Std} \beta=.398, \mathrm{CR}=3.709, \mathrm{p}<0.01)$, between PIA and $\mathrm{BP}(\operatorname{Std} \beta=.227$, $\mathrm{CR}=3.335, \mathrm{P}<0.01)$, between PIA and $\mathrm{BP}(\operatorname{Std} \beta=.355, \mathrm{CR}=4.925, \mathrm{P}<0.01)$. This result is indicated that $\mathrm{H} 1, \mathrm{H} 2, \mathrm{H} 3, \mathrm{H} 4, \mathrm{H} 5$ are accepted. 


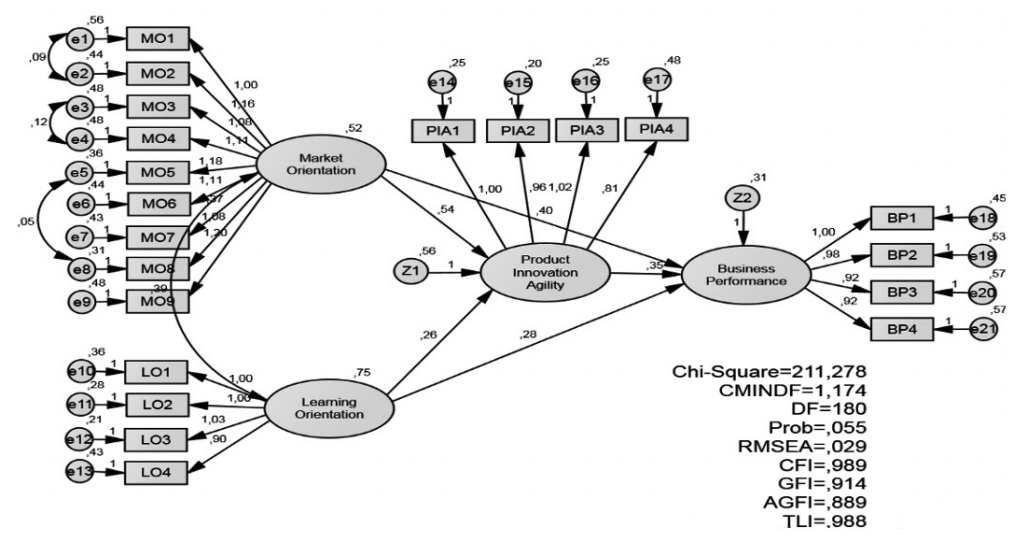

Figure 2. Final structural model

Source: data was calculated by SEM

PIA test becomes a mediating variable between $\mathrm{MO}$ and BP, the Sobel test approach (1982) is used. The result of the Sobel test is shown 3,354 ( $\mathrm{p}<0.01$ ), PIA is able to mediate the relationship between $\mathrm{MO}$ and $\mathrm{BP}$, so $\mathrm{H6}$ is accepted. The total indirect effect is 0.895 $(0.540+0.355)$ greater than the direct effect of 0.398 , so PIA has an important role in partially mediating the relationship between MO and BP. Furthermore, the result of the PIA test as a mediating variable between $\mathrm{LO}$ and $\mathrm{BP}$ indicated the Sobel test of 2,447 $(\mathrm{P}<0.01)$, PIA was able to mediate the relationship between $\mathrm{LO}$ and $\mathrm{BP}$ so that $\mathrm{H} 7$ was accepted. The total indirect effect is $0.620(0.265+0.355)$ greater than the direct effect of 0.227 , so PIA has an important role in partially mediating the relationship between LO and BP. Thus, PIA has a big role in mediating the relationship between $\mathrm{MO}$ and $\mathrm{LO}$ on BP.

\section{Discussion}

Market orientation significantly affects product innovation agility. The culture to understand the needs and desires of customers encourage creative industry to learn so that it has effect on product innovation agility. The strong organizational culture to have confidence and value that puts customers in every business decision will encourage creative industry players to develop product innovation agility based on customer expectations. The market orientation which becomes a business decision is realized in the form of value added for the consumer, understanding the needs of the consumers, providing satisfaction for the consumer, sharing of competitor information, the fast response of the competitors' actions and the competitor's strategy, coordinating among internal functions, always sharing information among teams 
and building cooperation to formulate the strategies. The ability of companies to understand customers, competitors, and inter-functional coordination will encourage companies to develop products according to customer needs and be flexible in production according to market demand. Market orientation also encourages companies to always adapt to customer needs and be flexible to develop unique products and different from competitors. The results of this study support the previous research which states that customer orientation by understanding customer expectations and feedback can drive the organization's speed and agility to innovate new products (Elkareem et al., 2011). Similarly, agility becomes as a key to develop new products to be able to meet market needs (Schuh et al., 2017)these processes pursue the target of limiting both time-to-market and resources associated with the realisation of innovative products. In the case of physical products, agile development in the form of highly iterative prototyping is further rmore employed for assuring a stable ramp-up phase. The goal of this paper is the creation of an adaptive engineering change management (ECM.

Learning orientation significantly affects product innovation agility. Learning orientation that is directed at strengthening employee skills to develop unique and different products requires agility to innovate products according to customer needs. Likewise, high trust among employees to always think a change will drive the speed of product innovation according to market needs. The results of the study are in accordance with the opinion that learning orientation improves innovation capabilities that can be implemented in the form of ideas, processes, products and services (Day, 1994), and learning orientation can improve company's innovativeness (Mahmoud, 2016). The commitment to learn the importance of market orientation is necessary for the organization to develop the product innovation agility. The result of this study supports the previous research conducted by (Elkareem et al., 2011), it is stated that learning orientation can enhance experience and knowledge to increase the agility of new product innovations.

Market orientation significantly affects business performance. This result study is in line with the findings of the previous research which states that market orientation can improve business performance (Nikraftar \& Momeni, 2017; Ho et al., 2018; Masa'deh et al., 2018technology orientation entrepreneurial orientation; Bhattarai et al., 2019; Musa et al., 2019). Creative industry players should consider every business decision to be market-oriented. The policy is taken in the form of consumer orientation in the form of value-added for consumers, understanding the needs of consumers, providing satisfaction for consumers. Furthermore, competitor-oriented should also be considered in the form of competitor information sharing, quick response of competitors' actions and competitor strategies, as well as inter functional coordination (inter-functional coordination, sharing information among teams and formulating cooperation strategies). 
Product innovation agility significantly affects business performance. The ability of companies to develop products according to their needs and provide more value for customers will expand market share. In addition, the company also has the ability to regulate the amount of production according to market demand so as to create cost efficiency and have an impact on increasing company profits. This findings support the assertion that agility will be able to improve market performance when decision makers have market skills, experience, learning orientation (Nemkova, 2017), and product innovation capability will be able to improve company's performance (Sulistyo \& Siyamtinah, 2016). Likewise, organizational agility has a strong influence on company performance (Ravichandran, 2018). The capabilities of innovation taken by creative industry actors are outlined in the form of introduction of new products, application of new technology products, product differentiation, market entry with new products, which can boost both sales and profit and increase return on assets. The result of this study support the finding of the better product design can increase sales growth, as conducted by (Dirisu, 2013).

Learning orientation significantly affects business performance. The result support the previous finding that states that learning orientation with a strong commitment lead to achieve the vision and goals as well as improve business performance (Martinette, 2006). Learning orientation can improve business performance (Aloulou, 2018). The commitment to learn importance of market orientation is necessary for the organization to gain insight about the market, customers, and competitors. Business decision can be described in the increased employees' skill, developing trust among employees and always thinking about the changes in the face of competition. The result of this study also indicates that market learning orientation play a mediator role between market orientation and business performance. The culture to understand the needs and desires of customers encourage creative industry players to learn so that it has an effect on business performance.

\section{Conclusion}

The result shows the importance of market orientation to improve the creative industry performance in Indonesia. The organizational culture has the confidence and value that puts customers on every business decision. It encourages the creative industry to improve the product innovation agility based on the customers' expectation. Learning based on market-oriented is essential to enhance the organizational ability in order to gain market knowledge, customers and competitors. Decision making in market-oriented business leads the product innovation agility and learning orientation and enhance the performance of creative industry. 
In managerial implication, the performance of the creative industry can be improved through marketing programs that is market-oriented. Market-oriented in marketing policy can be done by knowing the customer orientation, competitor orientation and inter functional coordination in accordance with environmental dynamics. Creativity is needed by the creative industry to improve product innovation agility according to market requirement. Improving the commitment to learn can gain knowledge of markets, customers and competitors. The theoretical implication of this research is that the performance of creative industry can be improved by developing market-oriented program, product innovation agility and learning orientation simultaneously. The role of market orientation and learning orientation in improving business performance will be more effective if it is done indirectly through product innovation agility.

\section{Limitation and Future Research}

The finding of this study is expected to contribute in the development of science, especially management science. The limitation of this research focuses only on the creative industry of fashion sector with a relatively small sample size and does not separate the scale of micro, small and medium enterprises. Leaders or managers of creative industries have different abilities in developing their business. They also have different views and behaviors towards the willingness to learn and understand market changes. Future research can be applied to the business sector with a larger scale and wider geographical area.

\section{References}

Abi, M., \& Abdul, S. (2011). The Measurement of Entrepreneurial Personality and Business Performance in Terengganu Creative Industry. International Journal of Business and Management, 6(6), 183-193. https://doi. org/10.5539/ijbm.v6n6pl83

Aliyu, R. M., Ahmad, T., \& Nordin, N. B. (2019). The Mediating Role of Innovation on Access to Finance and Business Performance of Women Entrepreneurs. International Journal of Academic Research in Business and Social Sciences, 9(3), 147-159. https://doi.org/10.6007/IJARBSS/v9-i2/5606

Aloulou, W. J. (2018). Studying the influences of learning orientation and firm size on entrepreneurial orientation - firm performance relationship in Saudi context. Middle East J. of Management, 5(2), 137. https://doi. org/10.1504/mejm.2018.091134

Ansah, M. O., \& Chinomona, R. (2017). Analysis of Market Orientation on Business Performance in the Multinational Service Industries. Journal of Social Sciences, 13(1), 40-52. https://doi.org/10.3844/jssp.2017.40.52

Asikhia, O. (2014). Customer Orientation and Firm Performance among Nigerian Small and Medium Scale Businesses. International Journal of Marketing Studies, 2(1). https://doi.org/10.5539/ijms.v2n1p197

Bereket M. B. (2017). Entrepreneurial orientation, market orientation and performance of SMEs in the manufacturing industry: evidence from Ethiopian enterprises. Management Research Review, 40(3), 1-24. https://doi. org/10.1108/MRR-07-2016-0173 
Bernardes, E. S., \& Hanna, M. D. (2009). A theoretical review of flexibility, agility and responsiveness in the operations management literature Toward a conceptual definition of customer responsiveness, International Journal of Operations \& Production Management, 29(1), 30-53. https://doi.org/10.1108/01443570910925352

Bhattarai, C. R., Kwong, C. C. Y., \& Tasavori, M. (2019). Market orientation, market disruptiveness capability and social enterprise performance: An empirical study from the United Kingdom. Journal of Business Research, 96(March 2017), 47-60. https://doi.org/10.1016/j.jbusres.2018.10.042

Carmeli, A., \& Dothan, A. (2017). Technological Forecasting \& Social Change Generative work relationships as a source of direct and indirect learning from experiences of failure : Implications for innovation agility and product innovation. Technological Forecasting \& Social Change, 119(Juni), 27-38. https://doi.org/10.1016/j. techfore.2017.03.007

Chang, C. H. (2011). The Influence of Corporate Environmental Ethics on Competitive Advantage: The Mediation Role of Green Innovation. Journal of Business Ethics, 104(3), 361-370. https://doi.org/10.1007/s10551-0110914-x

David J Teece.; Margaret A. Peteraf., S. L. (2016). Dynamic Capabilities and Organizational Agility: Risk, Uncertainty and Entrepreneurial Management in the Innovation Economy. California Management Review, 58(4), 13-35. https://doi.org/10.1525/cmr.2016.58.4.13

Day, G. S. (1994). Continuous Learning About Markets. Calfornia Management Review, (summer), 9-31. https:// doi.org/10.1177/002224299405800404

Dutta, D. K., Gupta, V. K., \& Chen, X. (2016). A Tale of Three Strategic Orientations: A Moderated-Mediation Framework of the Impact of Entrepreneurial Orientation, Market Orientation, and Learning Orientation on Firm Performance. Journal of Enterprising Culture, 24(03), 313-348. https://doi.org/10.1142/s0218495816500126

Ebrahimi, P., Shafiee, B., Gholampour, A., \& Yousefi, L. (2018). Impact of organizational innovation, learning orientation and entrepreneurship on SME performance: The moderating role of market turbulence and ICT. Contributions to Management Science. https://doi.org/10.1007/978-3-319-71722-7_23

Elkareem, A., Alzoubi, H., Al-otoum, F. J., Karim, A., \& Albatainh, F. (2011). Factors Assosiated Affecting Organization Agility of Product Development, International Journal Reviews in Applied Sciences, 9(3), 503-516. www. researchgate.net.

Fernandes, C. A., Hernández Mogollón, J. M., \& Ascensão, R. J. (2019). The relationship between market orientation, customer loyalty and business performance: A sample from the Western Europe hotel industry. Tourism and Hospitality Research, 20(2), 1-12. https://doi.org/10.1177/1467358419829179

Hair, J. F. (2010). Multivariate Data Analysis. Pearson Prentice Hall.USA.

Herman, H., Hady, H., \& Arafah, W. (2018). The Influence of Market Orientation and Product Innovation on the Competitive Advantage and Its Implication toward Small and Medium Enterprises (UKM) Performance. International Journal of Science and Engineering Invention, 04(08), 8-21. https://doi.org/10.23958/ijsei/ vol04-i08/02

Ho, K. L. P., Nguyen, C. N., Adhikari, R., Miles, M. P., \& Bonney, L. (2018). Exploring market orientation, innovation, and financial performance in agricultural value chains in emerging economies. Journal of Innovation \& Knowledge, 3(3), 154-163. https://doi.org/10.1016/j.jik.2017.03.008

Holbeche, L. S. (2018). Organisational effectiveness and agility. Journal of Organizational Effectiveness, 5(4), 302-313. https://doi.org/10.1108/JOEPP-07-2018-0044

Huang, J. W., \& Li, Y. H. (2017). The mediating role of ambidextrous capability in learning orientation and new product performance. Journal of Business and Industrial Marketing, 32(5), 613-624. https://doi.org/10.1108/ JBIM-01-2015-0017

Huber, G. (1991). Organizational Learning: The Contributing Processes and the Literatures Organizational Learning : The Contributing Processes and the Literatures. Organization Science, 2(1), 88-115. https://doi. org/10.1287/orsc. 2.1 .88 
Idrus, S. Al, Ahmar, A. S., \& Abdussakir, A. (2018). Contribution of Organizational Learning and Market Orientation on Business Unit Performance Mediated by Job Satisfaction at Dairy Cattle Milk Cooperatives in East Java, Indonesia. Journal of Reviews on Global Economics, 7, 207-216. https://doi.org/10.6000/19297092.2018.07.19

Jaakkola, M., Aalto, F., Aalto, F., \& Möller, K. (2010). Strategic marketing and business performance : A study in three European engineering countries.' Industrial Marketing Management, 39(8), 1300-1310. https://doi. org/10.1016/j.indmarman.2010.06.005

Jogaratnam, G. (2017). The effect of market orientation, entrepreneurial orientation and human capital on positional advantage: Evidence from the restaurant industry. International Journal of Hospitality Management, 60, 104-113. https://doi.org/10.1016/j.ijhm.2016.10.002

Karacaoglu, K., Bayrakdaro, A., \& San, F. B. (2013). The Impact of Corporate Entrepreneurship on Firms ' Financial Performance : Evidence from Istanbul Stock Exchange Firms. International Business Research, 6(1), 163-176. https://doi.org/10.5539/ibr.v6n1p163

Kaswuri, M., Ramayah M.A., Mohamad, T., (2016). The effect of market orientation as a mediating variable in the relationship between entrepreneurial orientation and SMEs performance. Nankai Business Review International, 7(1), 1-22. https://doi.org/org/10.1108/NBRI-08-2015-0019

Keskin, H. (2006). Market orientation, learning orientation, and innovation capabilities in SMEs: An extended model. European Journal of Innovation Management, 9(4), 396-417. https://doi.org/10.1108/14601060610707849

Kocak, A., Carsrud, A., \& Oflazoglu, S. (2017). Market, entrepreneurial, and technology orientations: impact on innovation and firm performance. Management Decision, 55(2), 248-270. https://doi.org/10.1108/MD-042015-0146

Kock, A., \& Gem, H. G. (2016). Antecedents to Decision-Making Quality and Agility in Innovation Portfolio Management, 00(00). https://doi.org/10.1111/jpim.12336

Kohli, A. K., Jaworski, B. J., \& Kumar. (1993). Measure of Market Orientation. Journal of Marketing Research, 30(4), 467-477. https://doi.org/10.1177/002224379303000406

Kohli, A. K. \& Jaworski, B.J., (1993). Market Orientation : Antecendents and Consequences. Journal of Marketing, 57(Julyi), 53-70. https://doi.org/10.1177/002224299305700304

Kuncoro, W., \& Suriani, W. O. (2018). Achieving sustainable competitive advantage through product innovation and market driving. Asia Pacific Management Review, 23(3), 186-192. https://doi.org/10.1016/j. apmrv.2017.07.006

Lakshman, C., Kumra, R., \& Adhikari, A. (2017). Proactive market orientation and innovation in India: The moderating role of intrafirm causal ambiguity. Journal of Management and Organization, 23(1), 116-135. https:// doi.org/10.1017/jmo.2016.11

Li, J. H. and Huang J.W. (2017). The mediating role of ambidextrous capability in learning orientation and. Journal of Business \& Industrial Marketing, 32(5), 613-614. https://doi.org/10.1108/JBIM-01-2015-0017

Mahmoud, M. A., Blankson, C., Owusu-Frimpong, N., Nwankwo, S., \& Trang, T. P. (2016). Market orientation, learning orientation and business performance: The mediating role of innovation. International Journal of Bank Marketing, 34(5), 623-648. https://doi.org/10.1108/IJBM-04-2015-0057

Mahmud, M., Aryanto, V. D. W., \& Hasyim, H. (2018). The Effect of Innovation capability and New Product Development on Marketing Performance of Batik SMEs. Polish Journal of Management Studies, 15(2), 132-142. https://doi.org/10.17512/pjms.2017.15.2.12

Mahto, R. V., McDowell, W. C., Kudlats, J., \& Dunne, T. C. (2018). Learning Orientation and Performance Satisfaction as Predictors of Small Firm Innovation: The Moderating Role of Gender. Group Decision and Negotiation, 27(3), 375-391. https://doi.org/10.1007/s10726-018-9566-x

Martinette, L. A. (2006). The Relationship Between Learning Orientation and Business performance The Moderating Effect of Competitive Adventage. Doctoral Dissertations.UMI. 
Martinette, L. A., \& Obenchain-leeson, A. (2012). The Relationship Between Learning Orientation And Business Performance And The Moderating Effect Of of Competitive Advantage : A Service Organization Perspective, Journal of Service Science 5(1), 43-58. https://doi.org/10.19030/jss.v5i1.6940

Masa'deh, R., Al-Henzab, J., Tarhini, A., \& Obeidat, B. Y. (2018). The associations among market orientation, technology orientation, entrepreneurial orientation and organizational performance. Benchmarking An International Journal, 25(8), 3117-3142. https://doi.org/10.1108/BIJ-02-2017-0024

Migdadi, M. M., Zaid, M. K. A., Yousif, M., Almestarihi, R., \& Al-Hyari, K. (2017). An Empirical Examination of Knowledge Management Processes and Market Orientation, Innovation Capability, and Organisational Performance: Insights from Jordan. Journal of Information \& Knowledge Management, 16(01), 1750002. https://doi. org/10.1142/s0219649217500022

Mitrega, M., Forkmann, S., Zaefarian, G. (2017). Networking Capability in Supplier Relationships and its Impact on Product Innovation and Firm Performance. International Journal of Operations and Production Management, 37(5), 1-62. https://doi.org/10.1108/IJOPM-11-2014-0517

Musa, C. I., Ramli, A., \& Hasan, M. (2019). How does the family capital and market orientation affect the business performance of the family business in the manufacturing sector? Advances in Economics, Business and Management Research, 75(ICMEMm 2018), 223-226. https://doi.org/10.2991/icmemm-18.2019.27

Najib, M., \& Kiminami, A. (2011). Innovation, cooperation and business performance: Some evidence from Indonesian small food processing cluster. Journal of Agribusiness in Developing and Emerging Economies, 1(1), 75-96. https://doi.org/10.1108/20440831111131523

Nemkova, E. (2017). The impact of agility on the market performance of born-global fi rms : An exploratory study of the ' Tech City' innovation cluster. Journal of Business Research, 80(May), 257-265. https://doi. org/10.1016/j.jbusres.2017.04.017

Nikraftar, T., \& Momeni, S. (2017). The effects of entrepreneurial orientation, market orientation and learning orientation on performance of ICT business. International Journal of Management Concepts and Philosophy, 10(4), 378. https://doi.org/10.1504/ijmcp.2017.087263

Nuryakin., Aryanto, V.D., Setiawan, M.B. (2018). Mediating effect of value creation in the relationship between relational capabilities on business performance. Contaduría y Administración, 63(1), 1-21. https://doi. org/10.22201/fca.24488410e.2018.1178

Nwokah, N. G., \& Maclayton, D. W. (2006). Customer-focus and business performance: The study of food and beverages organizations in Nigeria. Measuring Business Excellence, 10(4), 65-76. https://doi. org/10.1108/13683040610719281

Oliveira, S. R. M. (2017). High Radicality of Product Innovation and High Flexibility and High Agility of System of Manufacturing: Towards the Smart Factories. Procedia Manufacturing, 11(June), 1324-1334. https://doi. org/10.1016/j.promfg.2017.07.261

Raschke, R. L., David, J. S., \& Raschke, R. L. (2005). Business Process Agility, Proceedings of the Eleventh Americas Conference on Information Systems, 180, 335-360 Omaha, NE, USA August 11th-14th 2005, CIO Magazine.

Ravichandran, T. (2018). Journal of Strategic Information Systems Exploring the relationships between IT competence, innovation capacity and organizational agility. Journal of Strategic Information Systems, 27(1), 22-42. https://doi.org/10.1016/j.jsis.2017.07.002

Rebentisch, E., Conforto, E. C., Schuh, G., Riesener, M., Kantelberg, J., Amaral, D. C., \& Januszek, S. (2018). Agility factors and their impact on product development performance. Proceedings of International Design Conference, DESIGN, 1, 893-904. https://doi.org/10.21278/idc.2018.0236

Remli, N., Wan Daud, W. N., Zainol, F. A., \& Muhammad, H. (2013). A Proposed Conceptual Framework for Market Orientation and Innovation towards Takaful Performance in Malaysia. International Journal of Business and Management, 8(7), 100-106. https://doi.org/10.5539/ijbm.v8n7p100 
Schuh, G., Gartzen, T., Soucy-Bouchard, S., \& Basse, F. (2017). Enabling Agility in Product Development through an Adaptive Engineering Change Management. Procedia CIRP, 63, 342-347. https://doi.org/10.1016/j.procir.2017.03.106

Sharabati, A. A. A., Jawad, S. N., \& Bontis, N. (2010). Intellectual capital and business performance in the pharmaceutical sector of Jordan. Management Decision, 48(1), 105-131. https://doi.org/10.1108/00251741011014481

Shu, C., Zhou, K. Z., Xiao, Y., \& Gao, S. (2016). How Green Management Influences Product Innovation in China: The Role of Institutional Benefits. Journal of Business Ethics, 133(3), 471-485. https://doi.org/10.1007/ s10551-014-2401-7

Sin, L. Y. M., \& Tse, A. C. B. (2006). The Effecc of Relationship Marketing Orientation on Business Performance in the Hotel Industry. Journal of Hospitality \& Tourism Research, 30(4), 407-426. https://doi. org $/ 10.1177 / 1096348006287863$

Sin, L. Y., Tse, A. C., Yau, O. H., Lee, J. S., \& Chow, R. (2002). The effect of relationship marketing orientation on business performance in a service-oriented economy. Journal of Services Marketing, 16(7), 656-676. https:// doi.org/10.1108/08876040210447360

Sinkula, J. M., \& Baker, W. E. (1997). A Framework for Market-Based Organizational Learning : Linking Values , Knowledge , and Behavior. Journal of the Academic of Marketing Science, 25(4), 305-318. https://doi. org/10.1177/0092070397254003

Solano Acosta, A., Herrero Crespo, Á., \& Collado Agudo, J. (2018). Effect of market orientation, network capability and entrepreneurial orientation on international performance of small and medium enterprises (SMEs). International Business Review, 27(6), 1128-1140. https://doi.org/10.1016/j.ibusrev.2018.04.004

Slater, S.F \& Narver, J.C., (1990). The Effect of Market Orientation on Business Profitability. Journal of Marketing, 59(July), 63-74. https://doi.org/10.1177/002224299005400403

Sulistyo, H., \& Siyamtinah. (2016). Innovation capability of SMEs through entrepreneurship, marketing capability, relational capital and empowerment. Asia Pacific Management Review, 21(4), 196-203. https://doi. org/10.1016/j.apmrv.2016.02.002

Suliyanto, \& Rahab. (2012). The role of market orientation and learning orientation in improving innovativeness and performance of small and medium enterprises. Asian Social Science, 8(1), 134-145. https://doi. org/10.5539/ass.v8n1p134

Tajeddini, K. (2016). Analyzing the influence of learning orientation and innovativeness on performance of public organizations: The case of Iran. Journal of Management Development, 35(2), 134-153. https://doi.org/10.1108/ JMD-03-2015-0033

Tajeddini, K., \& Ratten, V. (2017). The moderating effect of brand orientation on inter-firm market orientation and performance. Journal of Strategic Marketing, 4488(February), 1-31. https://doi.or$\mathrm{g} / 10.1080 / 0965254 X .2017 .1293138$

Takata, H. (2016). Effects of industry forces, market orientation, and marketing capabilities on business performance: An empirical analysis of Japanese manufacturers from 2009 to 2011. Journal of Business Research, 69(12), 5611-5619. https://doi.org/10.1016/j.jbusres.2016.03.068

Venkatraman. (1986). Measurement of Business Performance in Strategy Research: A Comparison of Approaches. Academy of Management Review, 11(4). https://doi.org/10.5465/amr.1986.4283976

Wagner, H. T., Bogodistov, Y., Suradze, G. (2018). The Role of Marketing-Enabled Data Analytics Capability and Organisational Agility for Innovation: Empirical Evidence From German Firms. International Journal of Innovation Management, 22(04), 1850037. https://doi.org/10.1142/S1363919618500378

Wan Daud, W. N., Remli, N., \& Muhammad, H. (2013). Market orientation and performance: A study of Takaful performance in Malaysia. Asian Social Science, 9(4), 240-247. https://doi.org/10.5539/ass.v9n4p240

Wingwon, B. (2012). Effects of Entrepreneurship, Organization Capability, Strategic Decision Making and Innovation toward the Competitive Advantage of SMEs Enterprises. Journal of Management and Sustainability, 2(1), 137-151. https://doi.org/10.5539/jms.v2n1p137 
Zainul, M., Astuti, S., Arifin, Z., \& Utami, H. N. (2016). The Effect of Market Orientation toward Organizational Learning, Innovation, Competitive Advantage, and Corporate Performance. Journal of Administrative Sciences and Policy Studies, 4(1), 1-19. https://doi.org/10.15640/jasps.v4n1a1 